Journal of the Rubber Research Institute of Sri Lanka (2018) 98, 1-15

\title{
Coir pith and elephant dung: sowing substrates alternative to river sand for rubber (Hevea brasiliensis) nurseries
}

\author{
N M C Nayanakantha*, P S S Rodrigo**, E U M De Z Dissanayake* and \\ P Seneviratne* \\ * Rubber Research Institute of Sri Lanka, Dartonfield, Agalawatta, Sri Lanka \\ ** Department of Crop Science, Faculty of Agriculture, University of Ruhuna, Kamburupitiya, \\ Sri Lanka
}

\begin{abstract}
The sowing medium plays an important role in the production of good quality budded plants of rubber. Nowadays, the search for alternative high-quality and low-cost materials as sowing media in rubber nurseries is a necessity due to the increasing demand, environmental constraints and rising costs for river sand, the most widely used sowing medium during the last decades. To study the effects of different media on seed germination and seedling growth of rubber, experiments were conducted using river sand as the control and several other media viz., leached coir pith, dried elephant dung, reclaimed sea sand, fine quarry dust, course quarry dust, rubber wood saw dust and rubber wood chips. Germination attributes were significantly affected by the sowing medium. In the first experiment, seeds sown in coir pith recorded significantly higher values for germination percentage, germination value, germination index, rate of germination (lowest $E_{50}$ ), as compared to those in river sand (control) and other media. In the second and third experiment, seeds sown in coir pith and elephant dung recorded significantly higher values for germination as compared to those in other media and the values were on par with those in river sand. Seedlings raised from seeds sown in all media in the first experiment achieved buddable size (>6mm stem diameter) after three months. Considering the cost, availability and germination attributes, leached coir pith and dried elephant dung are identified as ideal sowing substrates alternative to river sand for rubber nurseries.
\end{abstract}

Key words: alternative sowing media, coir pith, elephant dung, river sand, rubber seeds

\section{Introduction}

Rubber (Hevea brasiliensis) seeds are used for raising root stock for bud grafting of clones. The successful production of healthy and vigorous root stock in rubber depends on the use of good quality seeds and management practices followed in the nursery. Rubber seeds are classified as recalcitrant that are susceptible to deterioration and lose their germination capacity in a short time (Dias et al., 2010). Fresh rubber seeds take 7-10 days to start germination in a sand bed and vigorous seedlings (about $50 \%$ of the early germinators) should be harvested every other day (only for three 
rounds up to 14 days), to raise stock plants even if the entire population germinates (Anon, 2016).

Seeds for commercial rubber nurseries are purchased from different suppliers who collect and store seeds for few days to weeks to supply them in bulk quantities. In certain nurseries, such seeds take more than 14 days to start germination in sand beds. Due to delays in germination, low germination percentage and asynchronous germination, large quantities of seeds are required to establish in germination beds. Moreover, the production of seeds in some rubber growing areas in Sri Lanka has been very poor in the recent past and therefore, finding sufficient quantities of good quality seeds during seed fall season is difficult. Hence, it is essential to search for alternative sowing media which can speed up germination, improve germination synchronicity and increase the percent germination of rubber seeds.

Seed germination can be influenced by many factors such as the type of substrate used and environmental factors. River sand has been used as the sowing medium for rubber seeds in commercial nurseries during the last decades. Due to the recent growth in the construction industry in Sri Lanka, the demand for river sand has increased tremendously (Ratnayake et al., 2014). Over exploitation of river sand, the rapid expansion of the mining of river bed and river bank sand, has caused widespread environmental, social and economic problems linked to the livelihoods of people, agriculture, health and land (Piyadasa, 2011). Because of these environmental constraints, the government of Sri Lanka has imposed various restrictions on the extraction and transportation of river sand. Consequently, high cost and scarcity of river sand have become the major problems faced by industrial workers in Sri Lanka. Therefore, the search for alternative high-quality and low-cost materials as sowing media in rubber nurseries is a necessity and the use of river sand must be progressively reduced. In the selection of new materials, environmental considerations have become as important as performance and economic cost. In this context, there has been a justifiable emphasis on materials derived from agricultural, industrial and municipal waste streams (Chong, 2005). The disposal of such materials already presents an environmental problem, and their re-use as sowing media might provide a convenient solution.

The use of materials like reclaimed sea sand and quarry dust in place of river sand is on the rise in building construction (Ratnayake et al., 2014; Rajapaksha and Sooriyarachchi, 2009).

An extensive research has been carried out regarding the use of different farm, industrial and consumer waste byproducts as components of nursery substrates (Chong, 2005). Different residual biomasses, such as coir (also known as coir pith, coir meal, coir dust, coco peat), a waste product of the coconut (Cocos nucifera) industry (Joseph and Jessy, 2015; Kumarasinghe et al., 2015), saw dust and wood chips (Joseph and Jessy, 2015) have been studied as partial or total substrate 
components. Tons of elephant dung is accumulated daily at Elephant Orphanage, Pinnawala (Kegalle District) and dried elephant dung can be collected free of cost for usage (personal communications, Assistant Curator, Elephant Orphanage). Therefore, this study was undertaken to ascertain the effectiveness of some alternative materials as sowing substrates for river sand in rubber nurseries.

\section{Materials and Methods \\ Experiment 1}

This experiment was conducted in a plant house at the Dartonfield Estate of the Rubber Research Institute of Sri Lanka (RRISL) from August December, 2017. Fresh rubber seeds of the clone RRISL 217 were collected and were sown in germination beds with different media viz., river sand (control), leached coir pith, reclaimed sea sand, fine quarry dust and course quarry dust at a thickness of $5 \mathrm{~cm}$ in randomized complete block design (RCBD) in 4 replicates. Forty seed were used in each treatment per replicate with a total of 160 and 1120 seeds in each treatment and all treatments, respectively. Watering was done manually using a watering can and providing the same amount of water for each treatment once daily. The management practices of germination beds were adopted as per recommendations of the Rubber Research Institute of Sri Lanka (Anon, 2016).

The effects of different sowing media were assessed by counting of the number of germinated seeds at 5, 7, 9, 11, 14 and 17 days after sowing. A seed was considered germinated when the tip of the radicle emerged free of the seed coat. Germination related parameters were calculated as follows;

a) The imbibition period (number of days from sowing to commencement of germination) was recorded.

b) Germination percentage: calculated as the percent of germinated seeds in relation to the total number of seeds per bed recorded on each day.

c) Rate of germination: the number of days taken to attain (emerge) $50 \%$ germination $\left(\mathrm{E}_{50}\right)$ was calculated according to Du et al. (2019).

$\mathrm{E}_{50}=\mathrm{t}_{\mathrm{i}}+\left[\left(\mathrm{N} / 2-\mathrm{n}_{\mathrm{i}}\right)\left(\mathrm{t}_{\mathrm{j}}-\mathrm{t}_{\mathrm{i}}\right)\right] /\left(\mathrm{n}_{\mathrm{j}}-\mathrm{n}_{\mathrm{i}}\right)(1)$

where $N$ is the final number of emerged seeds; $n_{\mathrm{i}}$ and $n_{\mathrm{j}}$ are the cumulative numbers of emerged seeds counted at time $t_{\mathrm{i}}$ and $t_{\mathrm{j}}$, respectively, where $n_{\mathrm{i}}<N / 2<n_{\mathrm{j}}$.

d) Mean germination time: calculated according to Du et al. (2019).

$$
\mathrm{MGT}=\frac{\sum D n}{\sum n}
$$

where $n$ is the number of emerged seeds on day $D$, and $D$ is the number of days counted from the beginning of the emergence

e) The germination value $(\mathrm{GV})$ : which is a composite value that combines both germination speed and total germination was calculated 
according to Jessy and Joseph (2015) by using the following formula

$\mathrm{GV}=(\mathrm{EDGs} / \mathrm{N}) \mathrm{X} \mathrm{GP} / 10$ :

where, GP: germination percentage at the end of the experiment. DG: daily germination speed obtained by dividing the cumulative germination percentage by the number of days since sowing, EDGs: total germination obtained by adding every DGs value obtained from the daily counts, $\mathrm{N}$ : total number of daily counts starting from the first germination, 10 is constant.

f) The emergence index (EI) was calculated as described by Du et al. (2019).

$\mathrm{EI}=\frac{\text { No.of emerged seeds }}{\text { Days of first count }}+\frac{\text { No.of emerged seeds }}{\text { Days of final count }}$

A preliminary experiment was conducted in the government rubber nursery, Gurugoda (Kaluthara District of the Wet Zone of Sri Lanka), from January-February, 2018, with a few seeds provided by the nursery using the aforementioned media, in order to evaluate the effects of sowing media under general nursery conditions. However, seeds provide by the nursery were not that much fresh when compared to that used in the experiment 1 in Dartonfield. Except for the fine quarry dust and course quarry dust, a satisfactory germination was recorded in all sowing media. Meantime, another preliminary experiment was conducted in the same nursery and during the same period using some other materials viz., dried elephant dung, rubber wood saw dust and rubber wood chips, along with river sand, to evaluate the effects of sowing media on seed germination. Seeds provided by the nursery were used for this experiment too. Satisfactory results were obtained from all media in this preliminary experiment too (results not shown). Therefore, to evaluate the effects of above sowing media, except for the fine and course quarry dust, on seed germination under general management conditions in government rubber nurseries, two large-scale experimental trials were conducted in Gurugoda and Middeniya nurseries belong to wet zone (WL1a) and intermediate zone (IL1b) from AugustSeptember, 2018.

\section{Experiment 2}

In Gurugoda nursery, polyclonal seeds provided by the nursery were sown in germination beds with different media viz., river sand (control), leached coir pith, dried elephant dung, saw dust, wood chips and reclaimed sea sand at a thickness of $5 \mathrm{~cm}$ on top of the existing sand beds in the nursery in a randomized complete block design (RCBD) in three replicates. There were six (6) treatments and a total of 23400,3900 and 1300 seeds were used for all treatments, each treatment and in each replicate respectively. The germinated seeds were counted after 7, 10, 12, 16 and 20 days of sowing, instead of alternative days, due to practical difficulties.

\section{Experiment 3}

In Middeniya nursery, polyclonal seeds provided by the nursery were sown in germination beds with different media viz., river sand (control), leached coir 
N M C Nayanakantha et al.

pith, dried elephant dung, saw dust, wood chips and reclaimed sea sand at a thickness of $5 \mathrm{~cm}$ on top of the existing sand beds in the nursery in a randomized complete block design (RCBD) in three replicates. There were six (6) treatments and a total of 23400,3900 and 1300 seeds were used for all treatments, each treatment and in each replicate respectively. The germinated seeds were counted after 7, 10, 12, 16 and 20 days of sowing, instead of alternative days, due to practical difficulties.

\section{Seedling attributes}

Germinated seeds resulted in the first experiment were transplanted in black polythene bags filled with soil. Polybags were arranged in a nursery according to an RCBD with five blocks, 30 plants per treatment. All other management practices were the same as recommended by the RRISL (Anon, 2016). Growth attributes of rubber seedlings raised from the experiment 1 were assessed after three months from transplanting. Ten plants from each treatment were removed and growth parameters viz., stem diameter, plant height, number of leaves, chlorophyll content and dry weights of shoots and roots were recorded.

\section{Data analysis}

Germination data were subjected to arcsin transformation where appropriate. Significance of the observed treatment differences was tested by analysis of variance using proc ANOVA procedure of the SAS software package (version 9.1) and significant means were separated using the least significant difference (LSD). An economic analysis was done for river sand and coir pith for an area of $0.05 \mathrm{~m}^{3}$.

\section{Results \\ Seed germination \\ Germination percentage}

Seed germination started 7 days after sowing in all sowing media in the first experiment (Fig. 1). However, in the second and third experiments, no germinated seeds were recorded within 7-10 days, but, germination started after 12 days of sowing (Fig. $2 \& 3$ ). Significant variations were observed in the germination of seeds in different media after different sowing days in all experiments (Fig. 1, $2 \& 3$ ).

In the first experiment, a significantly $(p \leq 0.05)$ higher germination percentage was recorded in coir pith as compared to river sand (control) and other media after $9(54.37 \%)$ days of sowing. Also, after 11 days, coir pith recorded a significantly higher germination percentage $(66.25 \%)$ as compared to other media and the value was on par with that in river sand (control). Nevertheless, after 14 days, no significant differences were recorded in seeds germinated in different media (Fig. 1). In the second experiment in Gurugoda nursery, the highest germination percentage was recorded in elephant dung after 12 (26\%), 16 $(58.66 \%)$ and $20(81.3 \%)$ days of sowing (Fig. 2). Nevertheless, after 16 days of sowing, germination value in elephant dung was on par with those in river sand (control) and coir pith (Fig. 2). In the third experiment in Middeniya nursery, the highest germination percentage $(39 \%)$ was recorded in river sand (control) after 12 days of sowing and the value was on par with those in coir pith, 
elephant dung and wood chips. After 16 days, higher germination values $(58.66 \%)$ were recorded in both river sand and elephant dung and the values were on par with those in wood chips and coir pith. Nevertheless, after 20 days, the highest value $(65.66 \%)$ was recorded in coir pith which is on par with those in river sand, elephant dung and wood chips (Fig. 3).

\section{Rate of germination (time taken to attain (emerge) 50 percent germination, $\left.\boldsymbol{E}_{50}\right)$}

A significant difference in the rate of germination was observed among treatments. In the first experiment, seeds sown in coir pith recorded significantly the highest rate of germination or the least time taken to attain 50 percent germination $\left(\mathrm{E}_{50}=8.63\right)$ when compared to other media and the value was on par with that in river sand (control) (Table
1). The highest $E_{50}$ value (12.17), the highest time taken to attain $\mathrm{E}_{50}$, was recorded in fine quarry dust and the value was on par with that in course quarry dust. In the second experiment in Gurugoda nursery, seeds sown in coir pith, elephant dung and river sand reached $50 \%$ germination after 16 days when compared to those in saw dust, wood chips and reclaimed sea sand (Fig. 2). In the third experiment in Middeniya nursery, seeds sown in coir pith, elephant dung, wood chips and river sand reached $50 \%$ germination after 16 days when compared to those in saw dust and reclaimed sea sand (Fig. 3). Moreover, seeds sown in saw dust and reclaimed sea sand in Middeniya nursery and those in saw dust and wood chips in Gurugoda nursery did not reach $50 \%$ germination even after 20 days of sowing (Fig. 2 \& $3)$.

Table 1. Effect of sowing media on germination attributes of rubber seeds

\begin{tabular}{lcclc}
\hline Treatments & $\begin{array}{l}\text { Germination } \\
\text { value }\end{array}$ & $\begin{array}{l}\text { Mean germi- } \\
\text { nation time }\end{array}$ & $\begin{array}{l}\text { Germination } \\
\text { index }\end{array}$ & $\begin{array}{l}\text { Rate of } \\
\text { germination }\left(\mathbf{E}_{\mathbf{5 0}}\right)\end{array}$ \\
\hline River sand (control) & $10.72 \pm 0.64^{\mathrm{b}}$ & $11.69 \pm 2.18^{\mathrm{ns}}$ & $3.25 \pm 0.10^{\mathrm{b}}$ & $8.95 \pm 0.26^{\mathrm{c}}$ \\
Coir pith & $13.55 \pm 0.78^{\mathrm{a}}$ & $9.26 \pm 0.90$ & $3.68 \pm 0.10^{\mathrm{a}}$ & $8.63 \pm 0.12^{\mathrm{c}}$ \\
Reclaimed sea sand & $9.45 \pm 0.48^{\mathrm{bc}}$ & $10.67 \pm 0.74$ & $3.07 \pm 0.07^{\mathrm{bc}}$ & $11.15 \pm 0.20^{\mathrm{b}}$ \\
Fine quarry dust & $7.25 \pm 0.99^{\mathrm{c}}$ & $13.24 \pm 1.26$ & $2.69 \pm 0.19^{\mathrm{c}}$ & $12.17 \pm 0.06^{\mathrm{a}}$ \\
Course quarry dust & $9.30 \pm 0.81^{\mathrm{bc}}$ & $10.91 \pm 0.78$ & $3.04 \pm 0.14^{\mathrm{bc}}$ & $11.62 \pm 0.06^{\mathrm{ab}}$ \\
\hline P value & 0.0089 & 0.3767 & 0.0179 & 0.0001 \\
LSD $(\mathrm{p} \leq 0.05)$ & 2.514 & - & 0.4309 & 0.5689 \\
\hline
\end{tabular}

Means followed by the same letter (s) are not significantly different at $p \leq 0.05$, according to Duncan's Multiple Range Test (DMRT). ns: non-significant, \pm indicates the standard error of the mean. 
N M C Nayanakantha et al.

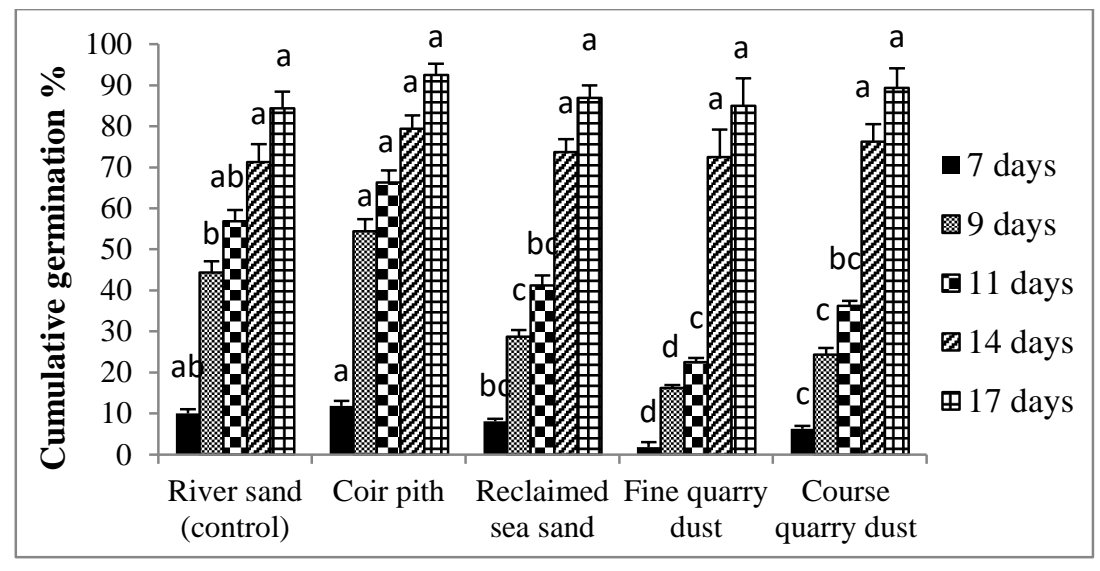

Fig. 1. Effect of different sowing media on germination percentage of rubber seeds after 7, 9, 11, 14 and 17 days of sowing in the plant house, Dartonfield (Experiment 1). Vertical bars above each mean denote the standard error. Letters indicate a significant difference at $\mathrm{p} \leq 0.05$ according to LSD

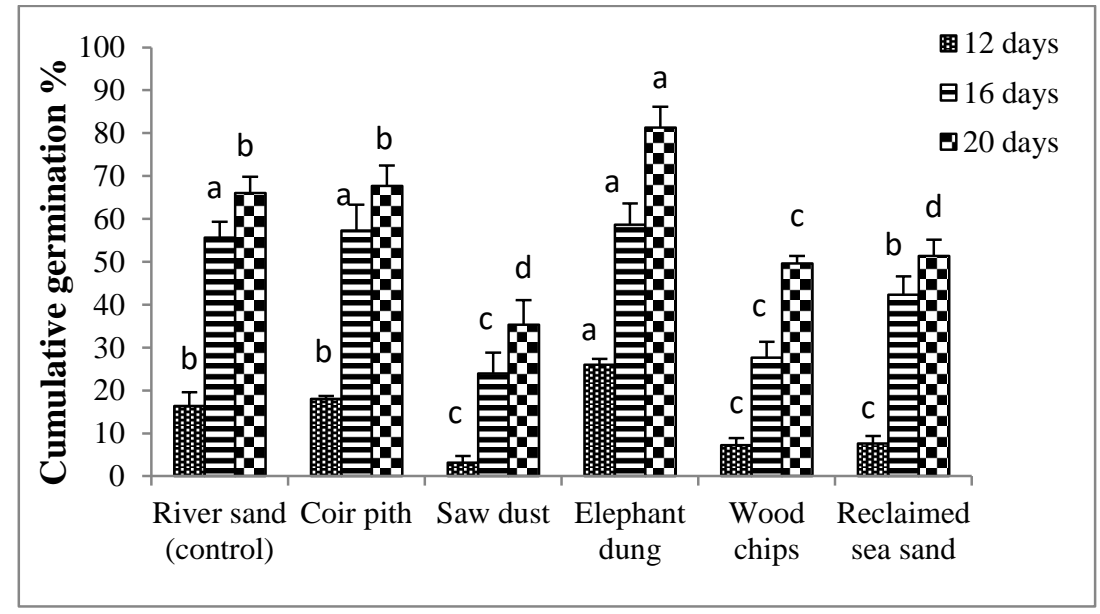

Fig. 2. Effect of different sowing media on germination percentage of rubber seeds after 12, 16 and 20 days of sowing in Gurugoda nursery (Experiment 2). Vertical bars above each mean denote the standard error. Letters indicate a significant difference at $\mathrm{p} \leq 0.05$ according to LSD 


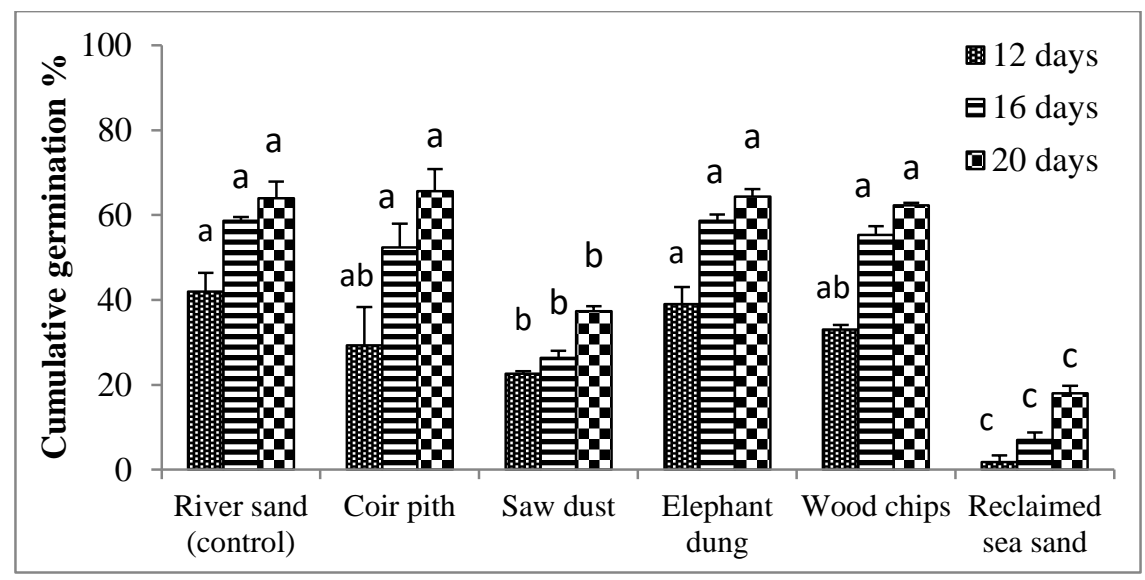

Fig. 3. Effect of different sowing media on germination percentage of rubber seeds after 12,16 and 20 days of sowing in Middeniya nursery (Experiment 3). Vertical bars above each mean denote the standard error. Letters indicate a significant difference at $\mathrm{p} \leq 0.05$ according to LSD

\section{Mean germination time, germination value and germination index}

The mean germination time did not differ significantly in different sowing media in the first experiment (Table 1). Coir pith recorded significantly the highest germination value as compared to other media and the control (river sand) (Table 1). The lowest germination value was recorded in fine quarry dust and the value was on par with that in course quarry dust and reclaimed sea sand (Table 1). The germination index was the highest (3.68) in coir pith as compared to that in river sand (control) and other media. The lowest value for germination index (2.69) was recorded in fine quarry dust and the value was in par with that in course quarry dust and reclaimed sea sand (Table 1).

\section{Seedling attributes}

In the first experiment, no significant differences were recorded for seedling attributes viz., stem height, no. of leaves, leaf chlorophyll content, dry weight of shoots and roots after three months from transplanting in polybags (Tables $2 \& 3$ ). However, seedlings raised from seeds sown in reclaimed sea sand recorded a significantly higher stem diameter as compared to those in river sand and the value was on par with that in coir pith and course quarry dust (Table 2). Nevertheless, seedlings raised from seeds sown in all media achieved buddable size (> 6mm stem diameter) after three months. Also, the seedlings raised from seeds sown in river sand, coir pith and elephant dung in the second and third experiment (Gurugoda and Middeniya nurseries) reached buddable size after 4-5 months respectively under general nursery management conditions (results not shown). 
N M C Nayanakantha et al.

Table 2. Effect of sowing media on seedling attributes of rubber after three months of transplanting in polybags

\begin{tabular}{lllll}
\hline Treatments & $\begin{array}{l}\text { Stem } \\
\text { height }(\mathbf{c m})\end{array}$ & $\begin{array}{l}\text { Stem diameter } \\
(\mathbf{m m})\end{array}$ & $\begin{array}{l}\text { No. of } \\
\text { leaves }\end{array}$ & $\begin{array}{l}\text { Leaf chlorophyll } \\
\text { content (SPAD value) }\end{array}$ \\
\hline River sand (control) & $58.9 \pm 3.07^{\mathrm{ns}}$ & $6.89 \pm 0.17^{\mathrm{b}}$ & $8.20 \pm 0.73^{\mathrm{ns}}$ & $8.95 \pm 0.86^{\mathrm{ns}}$ \\
Coir pith & $55.4 \pm 2.52$ & $7.46 \pm 0.26^{\mathrm{ab}}$ & $8.28 \pm 0.58$ & $8.63 \pm 3.05$ \\
Reclaimed sea sand & $71.0 \pm 4.05$ & $7.60 \pm 0.27^{\mathrm{a}}$ & $3.07 \pm 0.48$ & $9.20 \pm 1.26$ \\
Fine quarry dust & $55.8 \pm 2.31$ & $6.97 \pm 0.21^{\mathrm{b}}$ & $2.69 \pm 0.58$ & $7.20 \pm 1.29$ \\
Course quarry dust & $56.7 \pm 2.39$ & $7.36 \pm 0.18^{\mathrm{ab}}$ & $3.04 \pm 0.80$ & $8.20 \pm 1.17$ \\
\hline P value & 0.0516 & 0.0373 & 0.0783 & 0.4918 \\
LSD ( $\leq 0.05)$ & & 0.5737 & - & - \\
\hline
\end{tabular}

Means followed by the same letter (s) are not significantly different at $\mathrm{p} \leq 0.05$, according to Duncan's Multiple Range Test (DMRT). ns: non-significant, \pm indicates the standard error of the mean

Table 3. Effect of sowing media on dry weights of shoots and roots of rubber after three months of transplanting in polybags

\begin{tabular}{lcl}
\hline Treatments & Dry weight $(\mathbf{g})$ of shoot & Dry weight $(\mathbf{g})$ of root \\
\hline River sand (control) & $10.15 \pm 0.35^{\mathrm{ns}}$ & $4.10 \pm 0.26^{\mathrm{ns}}$ \\
Coir pith & $10.41 \pm 1.21$ & $5.33 \pm 0.82$ \\
Reclaimed sea sand & $14.58 \pm 1.10$ & $4.61 \pm 0.46$ \\
Fine quarry dust & $9.83 \pm 0.66$ & $3.89 \pm 0.18$ \\
Course quarry dust & $11.28 \pm 1.00$ & $3.76 \pm 0.30$ \\
\hline P value & 0.089 & 0.2256 \\
\hline
\end{tabular}
ns: non-significant, \pm indicates the standard error of the mean

\section{Economic analysis}

A cost analysis of the coir pith which recorded a significantly higher germination percentage as compared to river sand is shown in the Table 4 . The market prices of one tipper load (100 cubic feet) of river sand and coir pith are around Rs.14,000.00 and Rs.6,000.00 respectively. The cost of river sand and coir pith were around Rs.3.00 and Rs.26.00 per kg respectively, considering the weight of a tipper load/100 cubic feet of sand and coir pith are $4618 \mathrm{~kg}$ and $230 \mathrm{~kg}$ respectively. The quantities of river sand and coir pith required for an area of $0.05 \mathrm{~m}^{3}$ were $80 \mathrm{~kg}$ and $3.6 \mathrm{~kg}$ and the cost were Rs.242.00 and Rs.93.60 respectively. Around 50\% of sand can be reused as germination medium during the following year and therefore, the cost of sand for an area of $0.05 \mathrm{~m}^{3}$ would be around Rs.121.00. Approximately, one tipper load/100 cubic feet of river sand can cover $57 \mathrm{~m}^{2}$ of an area in the germination bed whilst one tipper load of coir pith or elephant dung can cover an area of $76 \mathrm{~m}^{2}$ in the germination bed with a height of $5 \mathrm{~cm}$. The dried elephant dung can be collected from Elephant Orphanage, Pinnawala free of cost. Transportation cost should be added to Elephant dung to be transported from Pinnawala to the nursery concerned. Similarly transportation cost for river sand and coir pith should be added considering the distance from the supplying place and area to the nursery concerned. 
Sowing substrates alternative to river sand

Table 4. Comparative cost analysis for an area of $0.05 m^{3}$ in a germination bed

\begin{tabular}{lcccc}
\hline Treatment & $\begin{array}{c}\text { Required amount }(\mathbf{k g}) \\
\text { for an area of } \mathbf{1 m} \mathbf{X} \\
\mathbf{1 m ~ X ~} \mathbf{0 . 0 5 m}\left(\mathbf{0 . 0 5} \mathbf{m}^{\mathbf{3}}\right) \\
\text { in the nursery }\end{array}$ & $\begin{array}{c}\text { Weight }(\mathbf{k g}) \\
\text { of } \mathbf{1} \text { tipper } \\
\text { load }(\mathbf{1 0 0} \\
\text { cubic feet) }\end{array}$ & $\begin{array}{c}\text { Price (Rs.) of } \\
\mathbf{1} \text { tipper load } \\
(\mathbf{1 0 0} \text { cubic } \\
\text { feet })\end{array}$ & $\begin{array}{c}\text { Price (Rs.) of } \\
\text { material for an } \\
\text { area of } \mathbf{0 . 0 5 \mathbf { m } ^ { 3 }}\end{array}$ \\
\hline Sand & 80 & 4618 & $14,000.00$ & 240.00 \\
Coir pith & 3.6 & 230 & 6000.00 & 93.60 \\
\hline
\end{tabular}

\section{Discussion}

\section{Seed germination}

Seed germination is a complex process, comprising events from seed imbibition to radicle emergence. In the present study, different germination responses were observed for the various sowing media. Rubber seeds used in the first experiment germinated within seven days, i.e. low imbibition time, in all sowing media. Nevertheless, rubber seeds used in the second and third experiment in Gurugoda and Middeniya nurseries started germination after 12 days (i.e. high imbibition time). This could be attributed to the differences in the quality of seeds used in different experiments.

Being recalcitrant, Hevea seeds lose their viability within a few days after falling from the tree. Therefore, it is essential to collect fresh seeds from early seed fall and transport to nurseries at the earliest possible. Fresh (high quality) rubber seeds generally take 7-10 days to start germination in a sand bed (Anon, 2016). Fresh seeds of the clone RRISL 217 were used in the first experiment. However, in the second and third experiment, polyclonal seeds that had been brought to each government nursery were used. Seeds for government rubber nurseries are purchased from different suppliers who collect and store seeds for a few days to weeks to supply them in bulk quantities. When the seeds were stored even for a few days, they lose their viability. Moreover, large quantities of seeds are required to be transported to each nursery on long distances, which can result in the deterioration of seeds to a certain extent. Therefore, these lowquality seeds require more time to start germination in sand beds. According to Wongvarodom et al. (2014), highquality rubber seeds had a greater emergence percentage and took less time to emerge compared to the low-quality seeds.

The current recommendation for harvesting germinated seeds from germination beds is to use only those germinated within the second week (until 14 days) of sowing, to ensure production of the vigorous rootstock. About $50 \%$ of the early germinators should be harvested every other day, only for three rounds, although the entire population germinates (Anon, 2016). Germination percentage/capacity in all sowing media in the first experiment after 14 days was above $70 \%$. Moreover, no significant differences were recorded for mean germination time among media. Mean germination time is a measure of the rate and time-spread of 
germination (Soltani et al., 2015). Therefore, all sowing media (river sand, coir pith, reclaimed sea sand, fine quarry dust and course quarry dust) appear to be suitable when fresh (high quality) rubber seeds are used. However, the highest germination index and germination value were recorded in coir pith as compared to river sand (control) and other media. The germination index represents the speed and uniformity of germination (Du et al., 2019) and the high germination value is indicative of high vigour of the seeds (ISTA, 1995). The time taken to reach $\mathrm{E}_{50}$ was lower in coir pith followed by river sand. $\mathrm{E}_{50}$ is the time taken for cumulative germination to reach $50 \%$ of its maximum and interpolate from the germination progress curve versus time (Soltani et al. 2001). The results show that coir pith is superior to river sand as a sowing medium. Supporting the present study, Joseph and Jessy (2015) reported that leached coir pith was ideal to river sand as a germination medium as far as availability, cost, and germination capacity are concerned.

In the second and third experiment with low quality seeds, the sowing media elephant dung, coir pith and river sand recorded a satisfactory germination percentage $(>50 \%)$ after 16 days of sowing in both Gurugoda and Middeniya nurseries. A growing medium should have various favorable characters such as light-weight, good porosity, welldrained but with optimum water holding capacity, slightly acidic with optimum cation-exchange-capacity, constant volume when wet or dry (Miller and Jones, 1995). Ndor et al. (2012) reported that good seed material contact and firmness of the medium contributed better moisture availability to trigger a better germination process. According to Jessy and Joseph (2015), the water holding capacity (WHC) of different media was in the order of coir pith $(937.33 \%)>$ sawdust $(271.62 \%)>$ wood chips $(227.688)>$ river sand $(30.48 \%>$ rock powder (11.91\%). Accordingly, coir pith recorded the highest WHC whilst rock powder (quarry dust) recorded the lowest. Coir pith provides a favorable balance of air and water to plant roots and it has a high re-wetting capacity (Blok and Wever, 2008). The physical appearance and properties of dried and crushed elephant dung are similar to that of coir pith and therefore, we can expect a high WHC in elephant dung too. In government nurseries, sand germination beds are irrigated daily throughout the germination period. It shows that irrigation intervals to germination beds filled with coir pith or elephant dung can be reduced to alternative days or once in two days and thereby, minimize labor cost while saving water. Very low germination percentage recorded (results not shown) in low-quality seeds sown in fine and coarse quarry dust in the preliminary experiment in Gurugoda nursery might be due to its poor water holding capacity and some other unfavorable properties.

Even though the WHC of river sand is less, the germination attributes in river sand are on par with those in coir pith. River sand was sufficiently firm and dense to hold the seeds in place during germination and it retained enough moisture for germination (Ekwu and Mbah, 2001). Although reclaimed sea 
sand recorded satisfactory seed germination attributes in the first experiment, it didn't perform well in the second and third experiment. This can be attributed to the differences in sand and seed qualities. The properties, especially the salt and chloride content in sea sand, may vary depending on the leaching duration. Sea sand stock piles should be kept inland for 1-2 years to remove chloride ions through natural washing before being used to construction purposes (Ratnayake et al., 2014). Reclaimed sea sand was purchased from one supplier in 2017 but from a different supplier in August 2018. Perhaps, germination had been negatively affected by salinity stress (the presence of high chloride $\left(\mathrm{Cl}^{-}\right)$(Ratnayake et al., 2014) and other ions in the latter sea sand). The process of germination starts with the uptake of water by the dry seed (imbibition) and is completed by when a part of the embryo, usually the radicle, penetrates the seed coat (Bewley, 1997). Salinity stress affects seed germination either through osmotic effects, by preventing or delaying germination (Welbaum et al., 1990), or through ion toxicity, which can render the seeds unviable (Huang and Reddman, 1995). In the second and third experiment, seeds sown in sawdust had a low germination percentage as compared to those in coir pith, elephant dung and river sand even though the WHC in sawdust was very high (Joseph and Jessy (2015). The sawdust used in the preliminary trial in Gurugoda was old and well dried. However, the sawdust used in the second and third experiment was somewhat fresh. Moreover, germination percentage in wood chips in Middeniya nursery was satisfactory but a low germination percentage was recorded in wood chips in Gurugoda nursery. Here, wood chips used in Gurugoda nursery were somewhat fresh as compared to those used in Middeniya nursery. The release of soluble tannin related phenolic compounds from fresh sawdust and wood chips (Thampan, 2000) might have contributed to the low germination percentage in seeds.

Several coir pith types (leached, partially leached and fresh) are available in the market. Although we used leached coir pith for the major experiments, other coir pith types were also tested in different sub experimental trials in Gurugoda nursery using both fresh and old seeds. In all the trials, satisfactory germination $(>50 \%)$ was recorded in both seed types sown in all three types of coir pith after 14 days. Interestingly, fungal infections/growth were not recorded in/ on seeds or in sowing media in all experiments throughout. Moreover, no seeds were rotten due to high moisture and bacterial infections. In general, nursery managers apply a fungicide solution, preferably of Captan, in sand beds before sowing seeds due to fear of fungal infection. Therefore, experimental trials were also conducted in Gurugoda nursery with or without a fungicide treatment in the sowing media such as river sand and elephant dung. None of the trials recorded fungal infections in any of the sowing medium even after one month irrespective of fungicide treatments. 
N M C Nayanakantha et al.

\section{Seedling growth}

Seedlings raised from seeds sown in different media in the first experiment showed no significant variations in growth parameters except for the stem diameter. Seedlings derived from seeds sown in reclaimed sea sand recorded a significantly higher stem diameter and the value was on par with that in coir pith and course quarry dust. This suggests that some substances in sea sand, probably mineral ions $\left(\mathrm{Na}^{+}\right.$and $\mathrm{K}^{+}$), might have induced some growth attributes in germinated seeds before transplanting in polybags. Nevertheless, seedlings raised from seeds sown in all media in the first experiment achieved buddable size after 3 months and those in the second and the third experiment achieved after 4-5 months and it showed that there was no effect of sowing media on growth of rubber seedlings.

\section{Economic analysis}

The performance of an alternative sowing medium must be balanced against its cost. This includes the market value of the material per unit volume, transport cost and the cost of any secondary processing required for its effective use (Lu et al., 2006). Coir pith can be purchased at a low price as compared to river sand. In order to minimize the long distance transportation cost, usage of coir pith can be encouraged in nurseries located in areas where coir pith is readily available. Dried and crushed elephant dung can be collected free of cost at Elephant Orphanage, Pinnawala, Kegalle and transported in bulk quantities similar to that of coir pith. Therefore, elephant dung may be an ideal alternative sowing medium for nurseries located especially in Kegalle district.

\section{Conclusion}

Seed germination in coir pith and elephant dung is superior to/on par with that in river sand. Environmental and economic benefits can also be enjoyed with elephant dung and coir pith where possible. Therefore, coir pith and elephant dung may be used as alternative substrates for river sand in rubber nurseries.

\section{Acknowledgments}

The authors wish to thank the nursery managers of Gurugoda and Middeniya nurseries for their support in conducting experiments. The support given by Mrs L D R M Bandaranayake, Deputy Director, Department of National Zoological Gardens and Mr H M A K Dissanayake, Assistant Curator, Elephant Orphanage, Pinnawala is highly appreciated. Statistical assistance given by $\mathrm{Dr}$ (Mrs) Wasana Wijesuriya, Principal Research Officer, Biometry Section, RRISL, is gratefully acknowledged.

\section{References}

Anon (2016). Production of budded plants. Advisory Circular. Rubber Research Institute of Sri Lanka.

Bewley, J D (1997). Seed germination and dormancy. The Plant Cell 9, 1055-1066.

Blok, C and Wever, G (2008). Experience with selected physical methods to characterize the suitability of growing media for plant growth. Acta Horticulture 779, 239-249. 
Chong, C (2005). Experiences with wastes and composts in nursery substrates. Hort. Technology. 15, 739-747.

Dias, L L C, Balbuena, T S, Silveira, V, Santa-Catarina, C, Schevchenko, A and Floh, E I S (2010). Two dimensional gel electrophoretic protein profile analysis during seed development of Ocotae catharinensis: A recalcitrant seed species. Brazilian Journal of Plant Physiology 22, 23-33.

Du, B, Luo, H, He, L, Zhang, L, Liu, Y, Mo, Z, Pan, S, Tian, H, Duan, $M$ and Tang, $X$ (2019). Rice seed priming with sodium selenate: Effects on germination, seedling growth, and biochemical attributes. Scientific Reports 9, 4311, 1-9. https:// doi.org/10.1038/s41598-019-40849-3.

Ekwu, G and Mbah, B N (2001). Effect of varying levels of fertilizer and some potting media on the growth and flowering response to Marigold (Target eracta L.). Nigeria Journal of Horticultural Sciences 5, 104-109.

Huang, J and Reddman, R E (1995). Salt tolerance of Hordeum and Brassica species during germination and early seedling growth. Can J Plant Sci. 75, 815-819.

International Seed Testing Association (1995). The Encyclopedia of seeds. In: Hand Book of Vigour and Test Methods, $3^{\text {rd }}$ Edition (Eds. J G, Hampton and D M Tekrony), Switzerland., ISTA, Zurich. P.745.

Joseph, P and Jessy, M D (2015). Coir pith: A cost effective alternative germination medium for rubber seed (Hevea brasiliensis). Rubber Science 28(3), 237246.

Kumarasinghe, H K M S, Subasinghe, S and Ransimala, D (2015). Effect of coco peat particle size for the optimum growth of nursery plant of greenhouse vegetables. Tropical Agricultural Research \& Extension 18(1), 51-57.
Lu, W, Sibley, J L, Gilliam, C H, Bannon, J S and Zhang, Y (2006). Estimation of U.S. bark generation and implications for horticultural industries. J. Environ. Hortic. 24(1), 29-34.

Miller, J H and Jones, N (1995). Organic and compost -based growing media for tree seedling nurseries. World Bank Technical Paper No. 264, Forestry Series.

Ndor, E, Dauda, N S and Chammang, H B (2012). Effect of germination media and seed size on germination and seedling vigour of fluted pumpkin (Telferia occidentalis Hook. F.). International Journal of Agricultural Sciences 2(3), 113-115.

Piyadasa, R U K (2011). River sand mining and associated environmental problems in Sri Lanka. Proceedings of the workshop held at Hyderabad, India, IAHS Publ., 349.

Rajapaksha, R W C N and Sooriyaarachchi, H P (2009). Feasibility of quarry dust to replace river sand as fine aggregate of concrete. Engineer, XXXX1I, (04), 3037.

Ratnayake, N P, Puswewala, U G A, Chaminda, S P, Ekanayaka, E M T M and Jayawardene, M N (2014). Evaluation of the potential of sea sand as an alternative to river sand for concrete production in Sri Lanka. Journal of Geological Society of Sri Lanka 16, 109-117.

Soltani, A, Galeshi, S, Zeinali, E and Latifi, N (2001). Genetic variation for and interrelationships among seed vigor traits in wheat from the Caspian Sea coasts of Iran. Seed Science and Technology 29, 653-662.

Soltani, E, Ghaderi, F, Baskin, C C and Baskin, J M (2015). Problems with using mean germination time to calculate rate of seed germination. Australian Journal of Botany, A-E. http://dx.doi.org/10. 1071/BT15133 
N M C Nayanakantha et al.

Thampan, P K (2000). Recycling of coconut biomass for sustainable production. Indian Coconut Journal 7, 5-6.

Welbaum, G E, Tissaoui, T and Bradford, K J (1990). Water relations of seed development and germination in muskmelon (Cucumis melo L.) Z. Sensitivity of germination to water potential and abscisic acid during development. Plant Physiol. 92, 10291037.
Wongvarodom, V, Duangiat, W, Santipracha, W and Sdoodee, S (2014). Effect of seed quality on field emergence and seedling performance of rubber (Hevea brasiliensis). Kasetsart J. (Nat. Sci.) 48, 376-382.

Address for correspondence: Dr N M C Nayanakantha, Head, Plant Science Dept., Rubber Research Institute of Sri Lanka, Dartonfield, Agalawatta, Sri Lanka. e-mail: nayanakanthachamil7@gmail.com 